\title{
Pengaruh Lingkungan Kerja Dan Karakteristik Individu Terhadap Kinerja Karyawan SMK Kartini
}

\author{
Maulana Sidiq Sedayu ${ }^{1}$, Rushadiyati ${ }^{2}$ \\ Program Studi Administrasi Bisnis Universitas Respati Indonesia \\ email: sidiqsedayu@gmail.com,rus.hadiyati@gmail.com
}

\begin{abstract}
ABSTRAK
SMK Kartini merupakan sekolah menengah kejuruan pariwisata swasta yang dahulunya adalah sekolah dasar berbahasa pengantar Belanda khusus diperuntukkan bagi gadis remaja. Berbeda dengan SD biasa, di Sekolah Kartini diberikan pelajaran tambahan memasak dan menjahit. Terletak di J1. Kartini, Pasar Baru, Jakarta Pusat, berawal dari “dana Kartini” yang digalakkan beberapa tokoh Belanda. Penelitian ini bertujuan untuk mengetahui apakah Lingkungan kerja (X1) dan Karakteristik Individu (X2) mempengaruhi tingkat kinerja karyawan (Y). Jenis penelitian ini adalah studi kasus. Penelitian ini dilakukan di SMK Kartini, Jl. Kartini Raya no. 26, Sawah Besar, Jakarta Pusat. Metode penelitian yang digunakan adalah penelitian kuantitatif dengan responden sebanyak 50 karyawan. Variabel dependen dalam penelitian ini adalah lingkungan kerja dan karakteristik individu, variabel independen dalam penelitian ini adalah kinerja karyawan. Pada penelitian ini instrumen penelitian yang digunakan adalah kuesioner dan analisis data yang digunakan adalah SEM dengan menggunakan aplikasi SmartPLS 3. Hasil penelitian ini menunjukkan bahwa 1) tidak terdapat pengaruh signifikan lingkungan kerja terhadap kinerja karyawan namun memiliki pengaruh positif, 2) terdapat pengaruh signifikan antara karakteristik individu terhadap kinerja karyawan, 3) terdapat pengaruh signifikan antara lingkungan kerja terhadap karakteristik individu.
\end{abstract}

Kata Kunci : Lingkungan Kerja, Karakteristik Individu, Kinerja Karyawan

\begin{abstract}
Kartini Vocational High School is a private tourism vocational high school that used to be a Dutch-language elementary school specifically for teenage girls. In contrast to regular elementary schools, Kartini Schools are given additional lessons on cooking and sewing. Located on J1. Kartini, Pasar Baru, Central Jakarta, started from the "Kartini fund" which was promoted by several Dutch figures. This study aims to determine whether the work environment (X1) and individual characteristics (X2) affect the level of employee performance (Y). This type of research is a case study. This research was conducted at Kartini Vocational High School, J1. Kartini Raya no. 26, Sawah Besar, Central Jakarta. The research method used is quantitative research with 50 employees as respondents. The dependent variable in this study is the work environment and individual characteristics, the independent variable in this study is employee performance. In this study, the research instrument used was a questionnaire and the data analysis used was SEM using the SmartPLS 3 application.The results of this study
\end{abstract}


indicate that 1) there is no significant effect of the work environment on employee performance but has a positive influence, 2) there is a significant influence between individual characteristics on employee performance, 3 ) there is a significant influence between the work environment on individual characteristics.

Keywords : Work Environment, Individual Characteristics, Employee Performance

\section{PENDAHULUAN}

Saat ini kondisi sekolah-sekolah mengalami penurunan kinerja, hal itu disebabkan oleh ketidakberhasilan sekolah dalam menjalankan manajemen sumber daya manusia. Keberhasilan perusahaan sangat ditentukan oleh kehandalan sumber daya manusianya, oleh karena itu harus diperhatikan faktor-faktor yang meningkatkan kinerja kayawan tersebut.

Lingkungan kerja adalah tempat dimana karyawan melakukan rutinitas sehari-hari dan semua hal baik benda dan non benda yang memperngaruhi karyawan dalam menjalankan tugas dan tanggung jawabnya. Pada dasarnya sekolah sangat perlu untuk memperhatikan lingkungan kerja di sekolah yang dimilikinya, kerena lingkungan kerja yang baik akan membuat karyawan termotivasi untuk melakukan pekerjaan dengan lebih baik sehingga meningkatkan kinerja karyawan pada sekolah. Juga sebaliknya lingkungan sekolah yang buruk akan membuat karyawan terhambat dalam pekerjaan dan aktivitasnya.

Menurut Stewart (2009), lingkungan kerja adalah sekumpulan kondisi atau keadaan sekitar lingkungan kerja suatu perusahaan yang merupakan tempat bekerja karyawan dalam perusahaan tersebut. Lingkungan kerja secara langsung mempengaruhi karyawan yang melakukan pekerjaan di dalam perusahaan. Kontrasnya lingkungan kerja di setiap organisasi dapat membuat ketidaknyamanan bagi karyawan dalam menyelesaikan kewajibannya, dapat membuat karyawan tidak bekerja dengan efisien.
Lingkungn kerja SMK Kartini berada di sebuah bangunan bekas belanda yang telah dijadikan cagar budaya oleh pemerintah provinsi DKI Jakarta, yang oleh karenanya bangunan sudah sangat tua dan tidak boleh diubah bentuk sama sekali karena status bangunan itu sendiri yang telah dijadikan cagar budaya oleh Pemprov DKI Jakarta dan hanya boleh direnovasi dengan syarat tidak boleh mengubah bentuk dan warna bangunan nya sama sekali.

Dikarenakan status gedung cagar budaya yang disandang oleh SMK Kartini menyebabkan pihak SMK Kartini tidak bisa merubah bentuk gedung sesuai dengan yang dibutuhkan oleh sekolah sehingga menyebabkan SMK Kartini memiliki ruang guru yang kurang luas, dan kurangnya jumlah meja dan kursi pada ruang guru.

Karakteristik individu adalah perbedaan manusia satu dengan yang lain. Karakteristik individu pada perusahaan adalah hal yang pasti terjadi karena setiap orang memiliki kepribadian yang berbeda. Karyawan atau SDM adalah individu yang memberikan energi, kemampuan, daya cipta, dan upaya mereka kepada organisasi untuk tercapai tujuan perusahaan.

Robbins (2006) menyatakan bahwa faktor-faktor yang tersedia dan dapat didefinisikan yang dapat diperoleh secara umum dari data yang dapat diakses dalam dokumen bagian personalia yang meliputi karakteristik individu adalah usia, jenis kelamin, status perkawinan, jumlah tanggungan dan lama bekerja karyawan dalam perusahaan. 
(Aktarina 2015) mengungkapkan bahwa karakteristik individu adalah ciri yang khas dalam menggambarkan perbedaan tiiap orang dalam hal motivasi kerja, inisiatif dalam bekerja, dan kemampuan untuk tetap menyelesaikan tugas yang diberikan sampai tuntas dan memecahkan masalah yang dihadapi juga adaptasi terhadap lingkungan yang dapat mempengaruhi kinerja masing-masing individu.

Pada SMK Kartini, pemberian tugas dan tanggung jawab yang tidak sesuai dengan kemampuan yang dimiliki oleh karyawan mengakibatkan tidak tuntasnya tugas yang diberikan, juga sikap (attitude) beberapa karyawan yang kurang mentaati peraturan yang berlaku di SMK Kartini.

Semua hal yang terdapat pada lingkungan kerja dan karakteristik individu dapat memiliki pengaruh terhadap baik atau buruknya kinerja karyawan. Lingkungan kerja dan karakteristik individu yang baik akan menghasilkan kinerja karyawan yang baik pula, begitu juga sebaliknya.

$$
\text { Mangkunegara }
$$

menegaskan bahwa kinerja pegawai merupakan hasil kerja pegawai yang

\section{KAJIAN TEORI \\ LINGKUNGAN KERJA}

Menurut Ruchi (Leblebici, 2012),

Kinerja karyawan sebagian besar ditentukan oleh lingkungan tempat mereka bekerja. Lingkungan kerja melibatkan semua aspek bertindak dan bereaksi pada tubuh dan pikiran karyawan. Di bawah psikologi organisasi, lingkungan fisik, mental dan sosial di mana karyawan bekerja dan pekerjaan harus dianalisis untuk efektivitas yang lebih baik dalam meningkatkan kinerja.

Tujuan utamanya adalah untuk menciptakan lingkungan yang menjamin kemudahan kerja dan menghilangkan semua penyebab frustrasi, kecemasan, dan kekhawatiran. Jika lingkungan kerja menyenangkan, maka kelelahan, kemonotonan dan kebosanan dapat tercermin dari kualitas dan kuantitas yang dilakukan oleh pegawai dalam melaksanakan tugasnya sesuai dengan tugas yang diberikan. Siagian (2002:286) bahwa kinerja pegawai dipengaruhi oleh beberapa faktor, yaitu: kompensasi, lingkungan kerja, budaya kepemimpinan, inisiatif dan motivasi, disiplin kerja, kepuasan kerja, komunikasi, dll.

Mathis dan Jackson (2007) mengungkapkan bahwa, semua hal baik yang dilakukan atau tidak dilakukan karyawan. Keber langsungan suatu perusahaan dioengaruhi oleh kinerja karyawannya. Perusahaan akan utung jika kinerja karyawannya baik, sebaliknya perusahaan akan mengalami kerugian meteril ataupun nonmateril jika kinerja karyawannya buruk.

Berdasarkan uraian di atas, penulis ingin mengetahui lebih dalam tentang pengaruh lingkungan kerja dankarakteristik individu terhadap kinerja karyawan untuk dapat mencapai tujuan perusahaan. Dengan demikian, penulis mengambil judul skripsi sebagai "Pengaruh lingkungan kerja dan karakteristik individu terhadap kinerja karyawan SMK Kartini."

diminimalisir dan kinerja dapat dimaksimalkan.

Menurut Nela Pima et al (2014) mengatakan bahwa lingkungan kerja adalah segala sesuatu yang ada di sekitar pekerja yang dapat mempengaruhi dirinya dalam melaksanakan tugas yang diberikan. Lingkungan kerja merupakan komponen yang sangat penting dalam karyawan melakukan aktivitas kerja. Kondisi lingkungan kerja dapat dikatakan baik apabila lingkungan kerja sehat, nyaman, aman dan menyenangkan bagi karyawan dalam menyelesaikan pekerjaannya.

Sedangkan menurut Zainul Hidayat (2012), lingkungan adalah keseluruhan atau setiap aspek dan gejala fisik dan sosial budaya yang mempengaruhi individu. Lingkungan kerja yang baik akan berdampak pada peningkatan kualitas kerja, mengurangi ketentraman di mata dan hasrat spiritual, 
dan yang terpenting moral kerja yang lebih baik dan prestise yang lebih baik bagi institusi yang bersangkutan. Lingkungan kerja merupakan tempat dimana karyawan melakukan aktivitas kerja. Lingkungan kerja dapat memberikan dampak positif dan negatif bagi karyawan dalam rangka mencapai hasil kerjanya.

Indikator lingkungan kerja menurut Nitisemito (1992: 159) adalah sebagai berikut:

1. Suasana kerja

Suasana kerja adalah suatu kondisi yang ada di sekitar karyawan yang sedang bekerja yang dapat mempengaruhi pelaksanaan pekerjaan karyawan. Lingkungan kerja ini akan menggabungkan lingkungan kerja, kantor dan bantuan kerja, kerapihan, penerangan, ketenangan mengingat berfungsinya hubungan antar individu untuk tempat tersebut (Saydam, 1996:381).

2. Hubungan dengan rekan kerja

Hubungan dengan rekan kerja adalah hubungan yang menyenangkan dengan harmonis dan tanpa kepentingan lain di antara rekanan. Salah satu elemen yang dapat mempengaruhi karyawan untuk tetap dalam satu perusahaan adalah hubungan yang menyenangkan antara rekan kerja.

3. Tersedianya fasilitas kerja

Artinya alat-alat yang digunakan untuk membantu kelancaran pekerjaan yang sudah lengkap. Tersedianya fasilitas kerja yang lengkap, meskipun bukan hal baru, merupakan salah satu siklus penunjang dalam bekerja.

\section{KARAKTERISTIK INDIVIDU}

Seperti yang diungkapkan oleh Hasibuan (2013:55) karakteristik individu adalah sifat bawaan individu yang dapat diubah oleh lingkungan atau pendidikan. Sementara itu, menurut I Wayan Subagiarta (2016) menyatakan bahwa karakteristik individu adalah karakter yang dimiliki oleh setiap individu yang tidak sama mulai dari satu individu ke individu lainnya. Aset utama dalam sebuah perusahaan adalah SDM, individu-individu yang memberikan tenaga, kemampuan, kreatifitas, dan karya mereka kepada perusahaan dengan tujuan agar sebuah perusahaan dapat tetap eksis. Setiap orang memiliki karakteristik individu yang berbeda dalam hubungannya satu sama lain.

Sebagaimana dikemukakan oleh Arief Subyantoro (2009) setiap orang memiliki perspektif, tujuan, kebutuhan, dan kemampuan yang berbeda satu sama lain. Perbedaan ini akan terbawa dalam bidang pekerjaan, yang akan mendorong kepuasan dari satu individu terhadap individu lainnya berbeda, meskipun mereka bekerja di tempat yang sama. Arief Subyantoro mengatakan bahwa indikator karakteristik individu meliputi:

1) Kemampuan, adalah batas seseorang untuk melakukan berbagai usaha dalam suatu tugas Robbins (2006). Dengan demikian, kemampuan merupakan fungsi dari pengetahuan dan keterampilan, sehingga persamaannya adalah A : f (K.S).

2) Nilai, seperti yang kemukakan oleh Robbin (2006), nilai individu tergantung pada pemenuhan pekerjaan, dapat menikmati, hubungan antar individu, pengembangan intelektual dan waktu untuk keluarga.

3) Sikap, menurut Robbins (2006) sikap adalah pernyataan evaluatif baik positif atau negatif mengenai objek, peristiwa, orang atau lainnya.. Dalam penelitian ini, sikap akan tertuju pada bagaimana perasaan seseorang tentang pekerjaan, kelompok kerja, pimpinan, dan organisasi.

4) Minat adalah perilaku seseorang yang membuat tertarik akan hal-hal tertentu, dalam hal ini seseorang akan disertai dengan perasaan kecenderungan akan hal tersebut. Minat seseorang dalam pekerjaan pun berbeda satu dengan lainnya (As'ad, 2004).

\section{KINERJA KARYAWAN}

Mangkunegara (2007: 9), mengartikan kinerja sebagai "perbedaan hasil kerja yang dicapai dengan keikutsertaan kerja karyawan yang dinyatakan per satuan unit waktu (biasanya setiap jam)". Selain itu, sebagaimana dikemukakan oleh 
Mangkunegara (2007: 9), mengatakan bahwa arti kinerka karyawan sebagai: "Ungkapan seperti output, efisiensi dan efektifitas yang dapat dihubungkan dengan produktifitas".

(Hanafi and Yohana 2017) Menurut Whitmore dalam Juliansyah (2013:270) kinerja adalah suatu aktifitas, prestasi, dan unjuk kemampuan. Menurut Eysenck (Kiruja E. K., 2013), kinerja karyawan didefinisikan sebagai kemampuan individu untuk melakukan dan selanjutnya menggabungkan kesempatan dan keinginan untuk melaksanakan pekerjaan mereka.

Sebagaimana dikemukakan oleh Mangkunegara (2000: 67) bahwa: "kinerja adalah hasil pekerjaan secara kualitas dan kuantitas yang dilakukan oleh seorang karyawan dalam menyelesaikan kewajibannya sesuai dengan tugas yang diberikan kepadanya". Kemudian, dikemukakan oleh Sulistiyani (2003: 223) "Kineraja merupakan perpaduan antara kemampuan, ikhtiar, dan kesempatan yang dapat dicermati dari hasil kerja karyawan.”. Sedangkan Hasibuan (2001: 34) mengemukakan "Kinerja (Pencapaian Kerja) adalah suatu pekerjaan yang diselesaikan oleh seorang individu dalam melakukan usaha-usaha yang diberikan kepadanya tergantung pada kemampuan, pengalaman dan kesungguhan serta waktu".

Sesuai Notoatmodjo (2003:23) menjelaskan bahwa kinerja karyawan adalah tindakan dalam perusahaan sejauh mana karyawan setia pada pekerjaan mereka dan seberapa besar penghargaan yang diberikan oleh organisasi sehubungan dengan pengembangan SDM.

Indikator Variabel Kinerja Karyawan menurut Simamora (2004:612):

1. Kuantitas

2. Kualitas

3. Ketepatan Waktu

\section{METODOLOGI PENELITIAN}

Penelitian ini termasuk jenis penelitian kuantitatif. Metode analisis data menggunakan analiasi Structural Equation Modeling-Partial Least Square (SEM-PLS) software Smart PLS versi 3. Populasi dalam penelitian ini adalah seluruh guru dan karyawan SMK Kartini Jakarta yang menurut data observasi penelitian berjumlah 50 orang. Adapun tahap-tahap pengujiannya adalah uji validitas, uji reliabilitas, inner model meliputi convergent validity, discrimnant validity, composite validity, cronbach's alpha, outer model meliputi uji path coefficient dan uji hipotesis.

\section{HASIL}

Berdasarkan penelitian yang telah dilakukan maka didapat hasil Uji Validitas Lingkungan Kerja (X1), Karakteristik Individu (X2) dan Kinerja Karyawan (Y) pada Tabel 1.

\section{Uji Validitas}

\begin{tabular}{|c|c|c|}
\hline $\begin{array}{c}\text { Korelasi Indikator Dengan } \\
\text { Variabel }\end{array}$ & Loading Factor & Keterangan \\
\hline X1.1 <-- Lingkungan Kerja & 0.653 & Valid \\
\hline X1.2<-- Lingkungan Kerja & 0.878 & Valid \\
\hline X1.3<-- Lingkungan Kerja & 0.829 & Valid \\
\hline X2.1 <-- Karakteristik Individu & 0.896 & Valid \\
\hline X2.2 <-- Karakteristik Individu & 0.792 & Valid \\
\hline X2.3 <-- Karakteristik Individu & 0.848 & Valid \\
\hline X2.4 <-- Karakteristik Individu & 0.875 & Valid \\
\hline Y1 <-- Kinerja Karyawan & 0.780 & Valid \\
\hline
\end{tabular}




\begin{tabular}{lll}
\hline Y2 <-- Kinerja Karyawan & 0.882 & Valid \\
Y3 <-- Kinerja Karyawan & 0.871 & Valid \\
\hline
\end{tabular}

\section{Uji Reabilitas}

\begin{tabular}{ll}
\hline & Composite Reliability \\
\hline Lingkungan kerja (X1) & 0.833 \\
Karakteristik individu (X2) & 0.915 \\
Kinerja Karyawan (Y) & 0.882 \\
\hline
\end{tabular}

\section{Inner Model}

Convergent Validity

Outer Loading

\begin{tabular}{cccc}
\hline Indikator & $\begin{array}{c}\text { Lingkungan Kerja } \\
(\mathbf{X 1})\end{array}$ & $\begin{array}{c}\text { Karakteristik } \\
\text { Individu (X2) }\end{array}$ & $\begin{array}{c}\text { Kinerja } \\
\text { Karyawan (Y) }\end{array}$ \\
\hline X1.1 & 0.653 & & \\
X1.2 & 0.878 & & \\
X1.3 & 0.829 & 0.896 & \\
X2.1 & & 0.792 & \\
X2.2 & & 0.848 & \\
X2.3 & & 0.875 & 0.780 \\
X2.4 & & 0.882 \\
Y1 & & 0.871 \\
Y2 & & & \\
Y3 & & & \\
\hline
\end{tabular}

Nilai AVE

\begin{tabular}{lr}
\hline & \multicolumn{1}{c}{$\begin{array}{l}\text { Average variance } \\
\text { extracted (AVE) }\end{array}$} \\
\hline Lingkungan kerja (X1) & 0.629 \\
Karakteristik Individu (X2) & 0.729 \\
Kinerja Karyawan (Y) & 0.715 \\
\hline
\end{tabular}


Composite Reability

\begin{tabular}{ll}
\multicolumn{2}{c}{ Nilai Composite Reability } \\
\hline & Composite Reliability \\
\hline Lingkungan kerja (X1) & 0.833 \\
Karakteristik individu (X2) & 0.915 \\
Kinerja Karyawan (Y) & 0.882 \\
\hline
\end{tabular}

Cronbach's Alpha

Nilai Cronbach's Alpha

\begin{tabular}{lc}
\hline & Cronbachs Alpha \\
\hline Lingkungan kerja (X1) & 0.717 \\
Karakteristik individu (X2) & 0.875 \\
Kinerja Karyawan (Y) & 0.800 \\
\hline
\end{tabular}

Outer Model

Uji Path Coefficient

\begin{tabular}{lr}
\multicolumn{2}{c}{$\boldsymbol{R}$-Square } \\
\hline R-square \\
\hline Lingkungan kerja (X1) \\
Karakteristik individu (X2) & 0.536 \\
Kinerja Karyawan (Y) & 0.598 \\
\hline
\end{tabular}

Uji Hipotesis

Path Coefficient

\begin{tabular}{|c|c|c|c|c|c|}
\hline & $\begin{array}{c}\text { Original } \\
\text { Sample }(\mathbf{O})\end{array}$ & $\begin{array}{c}\text { Sample } \\
\text { Mean (M) }\end{array}$ & $\begin{array}{l}\text { Standard } \\
\text { Deviation } \\
\text { (STDEV) }\end{array}$ & $\begin{array}{l}\text { T Statistics } \\
(|\mathrm{O} / \mathrm{STDEV}|)\end{array}$ & Sig \\
\hline $\begin{array}{l}\text { Lingkungan Kerja } \\
\text { (X1) -> Kinerja } \\
\text { Karyawan (Y) }\end{array}$ & 0.181 & 0.215 & 0.176 & 1.033 & 0.302 \\
\hline $\begin{array}{l}\text { Karakteristik } \\
\text { Individu (X2) -> } \\
\text { Kinerja Karyawan } \\
\text { (Y) }\end{array}$ & 0.631 & 0.607 & 0.170 & 3.702 & 0.000 \\
\hline $\begin{array}{l}\text { Lingkungan Kerja } \\
\text { (X1) -> } \\
\text { Karakteristik } \\
\text { Individu (X2) }\end{array}$ & 0.732 & 0.747 & 0.081 & 9.090 & 0.000 \\
\hline
\end{tabular}




\section{PEMBAHASAN}

1. H1 Lingkungan kerja (X1) berpengaruh terhadap Kinerja Karyawan (Y)

Tabel diatas menunjukkan bahwa pengaruh antara Lingkungan kerja (X1) dengan kinerja karyawan (Y) adalah tidak signifikan dengan T-Statistic sebesar 1,033 $(<1,96)$. Nilai original sample estimate adalah positif yaitu sebesar 0,181 yang menunjukkan hubungan antara lingkungan kerja (X1) dengan kinerja karyawan (Y) adalah positif. Dengan demikian hipotesis $\mathrm{H} 1$ dalam penelitian ini yang menyatakan bahwa "lingkungan kerja (X1) berpengaruh langsung terhadap kinerja karyawan (Y) ditolak.

2. H2 karakteristik individu (X2) berpengaruh terhadap kinerja karyawan (Y) Tabel diatas menunjukkan bahwa hubungan antara karakteritik individu (X2) dengan kinerja karyawan (Y) adalah signifikan dengan T-Statistic sebesar 3,702

(> 1,96). Nilai original sample estimate adalah positif yaitu sebesar 0,631 yang menunjukkan hubungan antara karakteristik individu (X2) dengan kinerja karyawan (Y) adalah positif. Dengan demikian hipotesis $\mathrm{H} 2$ dalam penelitian ini yang menyatakan bahwa karakteristik (X2) berpengaruh terhadap kinerja karyawan (Y) diterima.

3. H3 lingkungan kerja (X1) berpengaruh terhadap karakteristik individu (X2)

Tabel diatas menunjukkan bahwa pengaruh antara lingkungan kerja (X1) dengan karakteristik individu (X2) adalah signifikan dengan T-Statistic sebesar 9,090 (> 1,96). Nilai original sample estimate adalah positif yaitu sebesar 0,732 yang menunjukkan hubungan antara lingkungan kerja (X1) dengan karakteristik individu (X2) adalah positif. Dengan demikian hipotesis $\mathrm{H} 3$ dalam penelitian ini yang menyatakan bahwa lingkungan kerja (X1) berpengaruh terhadap karakteristik individu (X2) diterima.

\section{SIMPULAN}

Kesimpulan

Berdasarkan hasil perhitungan analisis SEM (Structural Equation Modeling) dan pembahasan pada bab v, maka didapatkan beberapa kesimpulan antara lain:

1. Lingkungan Kerja (X1) tidak memiliki pengaruh signifikan terhadap Kinerja Karyawan (Y), namun menunjukkan hubungan antara Lingkungan Kerja (X1) dengan Kinerja Karyawan (Y) adalah positif. Dengan demikian Hipotesis (H1) dalam penelitian ini yang menyatakan bahwa "Lingkungan Kerja (X1) berpengaruh terhadap Kinerja Karyawan (Y) ditolak.

2. Karakteristik Individu (X2) memiliki pengaruh signifikan terhadap Kinerja Karyawan (Y) dan menunjukkan hubungan antara Karakteristik Individu (X2) dengan Kinerja Karyawan (Y) adalah positif. Dengan demikian Hipotesis (H1) dalam penelitian ini yang menyatakan bahwa "Karakteristik Individu (X2) berpengaruh terhadap Kinerja Karyawan (Y) diterima.

3. Lingkungan Kerja (X1) memiliki pengaruh signifikan terhadap Karakteristik Individu (X2) dan menunjukkan hubungan antara Lingkungan Kerja (X1) dengan Karakteristik Individu (X2 adalah positif. Dengan demikian Hipotesis (H1) dalam penelitian ini yang menyatakan bahwa "Lingkungan Kerja (X1) berpengaruh terhadap Karakteristik Individu (X2) diterima.

\section{Saran}

Berdasarkan hasil penelitian yang telah dilakukan, maka penulis menyarankan antara lain :

1. Lingkungan Kerja (X1) tidak memiliki pengaruh signifikan terhadap Kinerja Karyawan (Y) dan memiliki hubungan positif. Saran :

Berdasarkan hasil penelitian diatas, indikator suasana kerja (X1.1) memiliki nilai terendah walaupun masih positif. Oleh karena itu pimpinan SMK Kartini dapat membuat suasana kerja di lingkungan SMK 
Kartini menjadi lengkap fasilitas kerjanya, lebih nyaman, juga menjaga ketenangan dan keharmonisan dalam lingkungan kerja SMK Kartini semisal dengan family gathering, makan bersama, arisan, atau hal lainnya yang dapat meningkatkan keeratan dan keharmonisan dalam lingkungan kerja SMK Kartini.

2. Karakteristik Individu (X2) memiliki pengaruh signifikan terhadap Kinerja Karyawan (Y) dan memiliki hubungan positif, Saran :

Berdasarkan hasil penelitian diatas, indikator kuantitas (Y1) memiliki nilai terendah walaupun masih positif. Oleh karena itu karyawan SMK Kartini dapat memaksimalkan dalam memberikan jumlah hasil kerja sesuai dengan yang diharapkan dan dibutuhkan SMK Kartini.

3. Lingkungan Kerja (X1) memiliki pengaruh signifikan terhadap Karakteristik Individu (X2) dan memiliki hubungan positif, Saran :

Berdasarkan hasil penelitian diatas, indikator nilai (X2.2) memiliki nilai terendah walaupun masih positif. Oleh karena itu SMK Kartini dapat menjaga, mempertahankan bahkan meningkatkan nilai-nilai yang dibutuhkan untuk mencapai hasil kerja yang memuaskan.

\section{DAFTAR PUSTAKA}

Abadylla, Harun Islami, and Subianto. (2013). "Pengaruh Lingkungan Kerja Karakteristik Individu Dan Motivasi Terhadap Kinerja Karyawan (Studi Pada Perguruan Tinggi Swasta IKIP PRGI Jember)." Journal of Chemical Information and Modeling 53(9):114.

Aktarina, Destia. (2015). "Pengaruh Karakteristik Individu, Pekerjaan Dan Lingkungan Kerja Terhadap Motivasi Dan Dampaknya Terhadap Kinerja Anggota Polri Di Polresta Palembang." Jurnal Media Wahana Ekonomika 12(3):42-54.
Ananda, Sella Selvia, and Bambang Swasto Sunuharyo. (2018). "Pengaruh Karakteristik Individu Dan Karakteristik Pekerjaan Terhadap Kinerja Karyawan Dengan Variabel Mediator Motivasi Kerja Karyawan (Studi Pada Karyawan Pt Petrokimia Gresik)." Jurnal Administrasi Bisnis 58(1):67-76.

Anshori, Muslich, and Sri Iswati. Metodologi penelitian kuantitatif: edisi 1. Airlangga

University Press, (2019)..

Hanafi, Bayu Dwilaksono, and Corry Yohana. (2017). "Pengaruh Motivasi, Dan Lingkungan Kerja, Terhadap Kinerja Karyawan, Dengan Kepuasan Kerja Sebagai Variabel Mediasi Pada Pt Bni Lifeinsurance." Jurnal Pendidikan Ekonomi Dan Bisnis (JPEB) 5(1):73-89. doi: 10.21009/jpeb.005.1.6.

Hidayat, Rahmat, and Anna Cavorina. (2018). "Pengaruh Karakteristik Individu Dan Lingkungan Kerja Terhadap Kinerja Karyawan Pt Cladtek Bi Metal Manufacturing." Journal of Applied Business Administration 1(2):337-47. doi: 10.30871/jaba.v1i2.617.

Kerja, Budaya. (2013). "Pengaruh Kedisiplinan, Lingkungan Kerja Dan Budaya Kerja Terhadap Kinerja Tenaga Pengajar." Jurnal Economia 9(2):191-200. doi: 10.21831/economia.v9i2.1809.

Nisakurohma, Agustya Hariski. (2018). "Pengaruh Karakteristik Individu Danngan Kerja Terhadap Kinerja Karyawan ( Studi Pada Karyawan PT Tigaraksa Satria Tbk Cabang Malang )." Administrasi Bisnis 61(3):109-15. 
Rahmawardani, Gabrella Bunga, Bambang Swasto Sunuharyo, and Fakultas Ilmu Administrasi. (2019). "Pengaruh Karakteristik Individu Dan Lingkungan Kerja Terhadap Kinerja (Studi Pada Karyawan PT. Gajah Tunggal, Tbk)." 73(2).

Subyantoro, A. (2009). Karakteristik individu, karakteristik pekerjaan, karakteristik organisasi dan kepuasan kerja pengurus yang dimediasi oleh motivasi kerja (studi pada pengurus kud di Kabupaten Sleman). Jurnal manajemen dan kewirausahaan, 11(1), 11-19.
Tambingon, C. K., B Tewal, I Trang, Bernhard Tewal, and Irvan Trang. (2019). "Pengaruh LIngkungan Kerja, Karakteristik Individu Dan Kompetensi Terhadap Kinerja Karyawan PT. Coco Prima Lelema Indonesia." 7(4):4610-19. 